\title{
The Village Forest as A Counter Teritorialization by Village Communities in Kampar Peninsula Riau
}

\author{
Rahmat Budiono ${ }^{1 *}$, Bramasto Nugroho ${ }^{2}$, Hardjanto ${ }^{2}$, Dodik Ridho Nurrochmat ${ }^{2}$ \\ ${ }^{1 *}$ Graduate School of Bogor Agricultural University, Dramaga main Road, Campus IPB Dramaga, Bogor, Indonesia 16680 \\ ${ }^{2}$ Department of Forest Management, Faculty of Forestry, Bogor Agricultural University, Academic Ring Road, Campus IPB \\ Dramaga, PO Box 168, Bogor, Indonesia 16680
}

Received March 5, 2018/Accepted September 24, 2018

\begin{abstract}
State hegemony over forest areas in practice is indeed more favorable to forestry corporations and eliminates a village community access. Data analyzed using Antonio Gramsci's hegemony theory and Laclau and Mouffe's hegemony to understand the movements of villagers to regain access to the forests. The results of this study indicate the emergence of antagonism between rural communities and companies was the impact of the abandonment of villagers from the forestry development. NGOs, as an organic intellectual has succeeded strengthen the village institutions to fight for remaining forests through permit of village forest, even though they have to compete with the biggest forestry company. The Permit of Village Forest in Kampar Peninsula has become the first social forestry permit in Riau Province. This condition is a fact the slow return of forest access to rural communities through social forestry programs. The Program of Social Forestry that was recently introduced by the state was not a counterhegemony (victory of the villagers against state hegemony), but it is reinforcing hegemony of state over forest areas.
\end{abstract}

Keywords: counter-hegemony, forest village community, non-governmental organization, reinforcing hegemony

*Correspondence author, email: rahmatbono@yahoo.com

\section{Introduction}

The forestry sector has real benefits for the life and livelihood of the Indonesian nation, both ecological, sociocultural and economic benefits, and this sector has a very high forward linkage effect compared to other sectors, which means that the forestry sector determines both economic performance and other sectors (Nurrochmat 2005; Nurrochmat et al. 2010; Nurrochmat et al. 2012; Iskandar 2015). The control of natural resources by the state as mandated in Article 33 of the 1945 Constitution, assigns the state to manage the earth, water, and natural resources in it for the greatest prosperity of the people, but in fact the exploitation of natural resources more favorable to the ruling class (Kartodihardjo et al. 2012; McCarthy et al. 2012).

The industrial tree plantations for wood production are among the fastest growing monocultures and currently being promoted as carbon sinks and energy producers. Such plantations are causing a large number of conflicts between companies and local populations, mostly in the tropics and subtropics (Gerber 2011). In Indonesia, industrial tree plantations, have led to deforestation, inefficiency in forest utilization, monopoly and oligopoly practices, a cause of lost traditional access for villagers to land and natural forest resource, such conditions have caused a large number of conflicts and make the forests as conflict zones between companies and local population. (Wollenberg et al. 2004; Peluso 2006; Prabowo et al. 2010; Scale Up 2012; Nurrochmat et al. 2014; Sudarmalik 2014).

Forestry laws/regulations are not sufficient to solve the problem, among others: inconsistent structure or content; risky in their implementation; too often changed and not well socialized, and still have the potential to incur high transaction costs (Nugroho 2013). State policy in the form of village community-based forest management has not been adequately supported by the village community because of the absence of state recognition of the existence of indigenous peoples and the fulfillment of the rights of forest communities (Nugroho 2011). Therefore, state policy must take sides with the people's economy and create an open and fair economic system (Hardjanto 2003; Hardojo 2008).

This article would like to understand how the awakening of the political consciousness of the village community and the strategies undertaken to fight for its tenure rights over forests.

Research on state hegemony for natural resources and counter-resistance from marginalized parties with access to counter-hegemony has also been carried out as in the hydrohegemony studies of the Nile, Jordan and Tigris and Euphrates River (Zeitoune \& Warner 2006; Cascao 2008; Menga 2016), hydro hegemony on water catchments in 
Kyrgyzstan-Kazakhstan, and Turkey (Warner 2008; Zinzania \& Mengab 2017), American hegemony of oil and geopolitics of the world (Bromley 1991), hegemony of real estate industry in Hongkong (Lee \& Tang 2016), carbon trading hegemony (Benjamin 2011), neoliberalist hegemony in urban forest development (Perkin 2011), and Forest Certification as hegemonic power (Blommfield 2012). Previous researchers have used the hegemonic theory to offer an understanding of how people effort for their access rights to natural resources, as well as the ruler's response to counterhegemony by the people.

\section{Methods}

Place and time The research was conducted in Segamai and Serapung villages which are located in Pelalawan District, Riau Province (Figure 1). The data also mined by interviewed to the key informants in the Ministry of Environment and Forestry (MoEF), Production Forest Management Agency of Region (PFMA) III Pekanbaru, Forest Service of Riau Province and Pelalawan District, Forest Management Unit of Tasik Besar Serkap (FMU of TBS). The study was conducted from March to August 2017.

The description of the location of study Segamai Village is located in Teluk Meranti Subdistrict Pelalawan District of Riau Province. Segamai village laid along the Kampar River in Teluk Meranti District in the south of Indragiri Hilir District. This village is adjacent to Pulau Muda Village on the western side, Gambut Mutiara Village, Serapung Village, Kuala Kampar Subdistrict in the east. The northern part with Teluk Meranti Subdistrict in the north adjacent to Siak District. Serapung is a village located in Serapung Island. The Serapung Village is adjacent to Topang Rangsang Timur Village District in north, Labuh Bilik Village. Teluk Meranti District in the south, Beringin Bay from Kuala Kampar
District in the east and Lanus Bay from Apit River District in west. Several industrial tree plantations surround both villages. Unfortunately, the industrials did not have a significant effect on the economic or social development and the villages are categorized into poor villages.

Data collection This research paradigm is social constructivism with the grounded theory approach. The grounded theory method does not test the hypothesis but sets out to find the philosophical theory for such a research situation. In this case, it is like a research activity that aims to understand the research situation and ultimately to find the implicit theory in the data (Straus \& Corbin 1990). Grounded theory is a living, growing, and adaptable methodology for generating, theoretical understanding of social phenomena, its approaches are sufficiently varied for use by researchers from many orientations and fields. These features particularly the conceptual freedom, have been noted as empowering for researchers (Coughlan et al. 2014). The data of this research is qualitative data, from observations, speeches, and written materials to be referred to as primary and secondary data. The primary data was collected by observation and in-depth interview, and the secondary data was collected by studying document reports and photo activities, videos, text in electronic and print media related to the research (Sitorus 1998; Bungin 2007; Samad 2010). Indepth interviews were conducted with many key informants at MoEF, PFMA III Pekanbaru, Forestry Service of Riau Province and Pelalawan District, non-governmental Organizations (Yayasan Mitra Insani, Jikalahari, AMAN, Bidara), FPMU of TBS, village officials, and community. Indepth interviews with informants conducted directly and separately within their respective environments. The informants were distinguished between key informants and ordinary informants. The key informants are informants who have extensive knowledge of various aspects studied in the

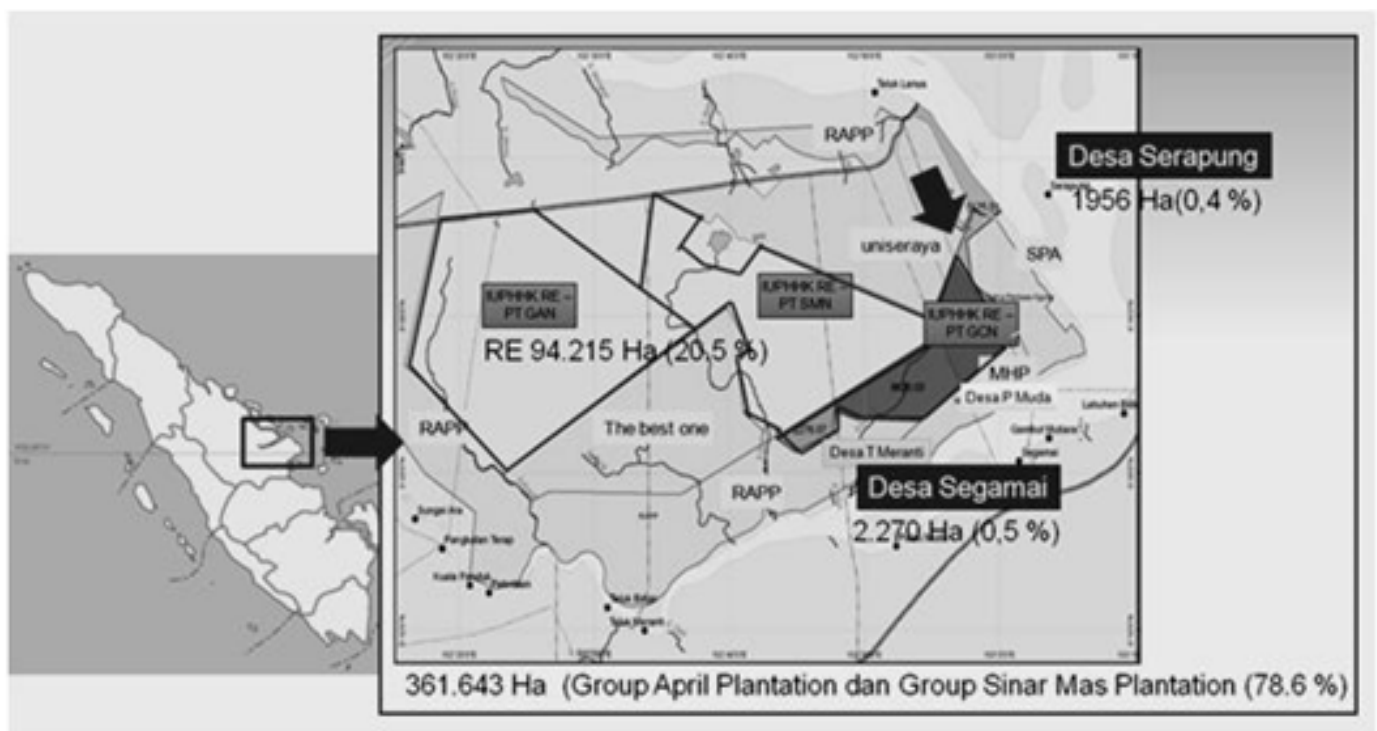

Figure 1 The location of study at Kampar Peninsula, Pelalawan District, Riau Province. 
village community, native or long domiciled, while the ordinary informants are informants who have extensive knowledge and experience about certain aspects of the village community environment (Polkinghorne 2005). The total number of informants in this study was 42 people, consisting: 6 people of NGO; 16 people apparatus (FPMU of TBS, MoEF, Forestry Service of Riau Province and Pelalawan District), and 19 people of villagers.

Data analysis There are three paths of qualitative data analysis, i.e., data reduction, data presentation, and conclusion. The data reduction begins with open coding that is converting the interview result in an interview script. Encoding is done on a small piece of text line by line interview script related to the hegemonic counter and the meaning of social movements, subsequently, begin writing memos as soon as we have ideas about our codes, new memos describe initial codes, and connect data to interpretations about this research. Second paths of qualitative data analysis are data reduction, begins with writing memos as a means of analysis. Memos are made on field conditions of concepts in which people present their views concerning the concept of counter-hegemony and the concept of contestation of remaining space within the forest area and on their insights into the concept of forest management practices in their villages. Final paths are the conclusion that is doing the theoretical sampling for analytically meaningful data. The point of theoretical sampling is to collect the data needed to develop the ongoing analysis further. After a category emerges from coding, the next step is to integrating, refining and writing theory. At this stage want to answer how the awakening of the political consciousness of the village community and the strategy undertaken to fight for his tenure rights to the forest. To understand the problem the authors wanted to test the concept of the hegemony of Antonio Gramsci (Cox 1983; Hunt 1990; Bocock 2001; Sugiono 2006; Patria \&Arief 2009) and social movements of village community resistance in the view of Ernesto Laclau and Chantal Mouffe (Hutagalung 2008; Laclau \& Mouffe 2008). Villagers have made the effort for right tenure rights since the colonial era (Peluso 2006; Prabowo 2010; Pranoto 2010; Lansing 2014). However, in the period of independence, the people still have to effort to seize the forest land that is eliminated by the state (Peluso 2006; Rachman 2017). In addition to using grounded theory analysis in the perspective of Gramscian, this paper was carried out by using the qualitative analytic approach with literature research method. This article also examines the history of state hegemonization of forests both at the state level and focuses on the loss of Wilayat Forests in the District of Pelalawan.

\section{Results and Discussion}

Community The role of the state in forest management in Indonesia has a long history, in relation to the ruling and governed opposition, between the state and the people. The history of natural resource management policies in practice often has a social impact that is detrimental and raises a variety of social conflicts (Suhendang 2013). The loss of the Wilayat Forest belonging to the village community is a manifestation of the State's hegemonization of forests which tends to overlook the rights of local communities. The relationship between the state and rural communities in the management of forest resources can be understood by tracing the dynamics of state forestry hegemony.

\section{The dynamics hegemony of state control over forests and village community access to the forest in Indonesia} During feudalism and colonial era, the conquest of the people was carried out through the existing feudal-structural agrarian ideology, so that the connection was in the form of patron-client (Leirissa 1999). Furthermore, during the period of ethical politics in 1901, the infiltration of European culture has formed a culture of Indies mixed culture of the Dutch East Indies (Indonesia) with Dutch Culture (Soekiman 2011). The priyayi group has taken the cultural system and used it as a channel of communication with the Netherlands and became an alliance or allied relationship (Leirissa 1999). However, cultural infiltration and ruling ideology to the people have not been able to hegemonize all layers of the village community. Rebellion and village community resistance are often triggered by injustice and misery due to slavery and the loss of village community land as occupied by landlords. Village community rebellion and resistance are increasingly frequent, which occurred between 1885 and 1904 as well as related to the land (Pranoto 2010). The state in the process of hegemonization in the later stages will use the pillars of power in the form of repressive actions against the people of both the rebellion of insurrection, exile and other physical torture as described Sunyoto (2015), Onghokham (2014), Nitayadnya (2013), Tamagola (2006), and Pranoto (2010). Forestry law formed after independence stated that every person is prohibited from occupying forest areas without permission so that the local community does not have access to state forests. The community will face repressive actions by the Forest Police as regulated in State Regulation Number 22 of 1985 (mandated by Article 15 of the Forestry Law Number 5 of 1967). The post-1998 reform era was established Forestry Law Number 41 of 1999, where legally people still cannot access the forest, except through licensing schemes in the form of social forestry programs. The issuance of Law Number 18 of 2013 strengthens the role of the state apparatus to safeguard state forests. The state hegemony of the forests that occur to date is not an integral hegemony, but the state hegemony over the forest area as a form of hegemony wrapped in coercive clothing or as a form of minimum hegemony (Hendarto 1993; Budiono 2017). As long as information is collected, it can be seen the role of organic intellectuals in maintaining a single ideology in maintaining state hegemony over the forest. Organic intellectuals influence the state to absorb the ideology of Domainverklaring (statement of state property) into dominant ideology and adopted by various regulations until post-independence. The policy domain will be dominated by a single ideology over time, albeit changed by ideological synthesis, but hegemonic discourse remains intact and dominant. However, the synthesis of hegemonic ideology is never static, as it absorbs the opposition. So the product of policy over time is a subversion of hegemonic interests (Scattergood 2004). The conflict between the village community and the company began when the foresters, who 
were formerly as a forestry service employees in the colonial period, after independence wanted full control of the forest were guided by the forestry ideology that viewed the local village community as a party that disturbed the interests of the forest (Peluso 2006). There was a contestation of interests involving local and central government, NGOs, legal practitioners, academics, sociologists and entrepreneurs in the formation of forestry law (Machmur 1999). The forester who has worked in colonial forestry institutions have managed to maintain the status of forest management back to the colonial era, where the state fully controls forest areas (MoF 1986; Buchy 2000; Fay \& Michon 2005).

History the lost of "Wilayat Forest" in Pelalawan District The creation of hegemonic territorial of the forest by a state and capitalist is a contribution to the discourse on indigenous peoples and the support of colonial-era scientists who marginalize indigenous peoples' spaces and are excluded by the state in the forest. The production of knowledge by scientists makes the process of territorializing the forest not only changing space but also producing political subjects and may be admitted by the state to the territory of its territory or excluded. Discursive formations of indigenous peoples with their forests play a role in creating of the form of hegemonic territorial (Servillo 2010; Lansing 2014).

The history of forest tenure by indigenous peoples in Riau Province can be traced from the history of the people of Petalangan Riau who live in Pelalawan District and have long lost their access to forests. This cannot be separated from the state control over forests in the early independence of the State of Indonesia which again implements state forest control (MoF 1986). The concept of control by the state in its implementation does not appear to be different from the principle of state domain (Rajagukguk 1995). The state also has a monopoly right to define a territory as forest area (Rahman 2017). According to Effendy (2008), the people of Riau have customary laws enshrined in a song Tombo Orang Petalangan and at that time to recognize the right of their forest area in the form of the Wilayat Forest (Hutan Tanah Perbatinan). The loss of the state recognition of Wilayat land began on October 20, 1945, when the Sultan of Pelalawan declared the Pelalawan Kingdom became a part of the Republic of Indonesia. Tengku Said Harun bin Tengku Said Hasyil bin Abubakar was the last Sultan of the Pelalawan, and since that time the Wilayat forest is formally no longer recognized as belonging to the Petalangan Village community but controlled by the state.

Even though the village community was customarily no longer own the Wilayat forest, but they have been practicing the traditional wisdom. Unfortunately, the territorialization of the forest by the state has removed the access to the forest and has triggered conflicts. Conflicts in the forestry sector between local village community and companies are increasingly high in Riau, including in Kampar Peninsula. Both parties feel they have a base of claim on the ownership or concession of the land they are disputing. According to the Riau, indicates an escalation of increasing agrarian conflicts between forest villagers and forestry and plantation corporations. In 2008, there were at least 24 conflicts in 85,771 ha, whereas, in 2010 , conflicts occurred on 230,492 ha of land with production forest status, in an area of 28,000 ha in protected and conservation areas, and in 84,079 ha with plantation status. In 2011, the conflicts were dominated by the plantation sector with 16 conflicts in 39,246 ha and the forestry sector with 14 conflicts in an area of 262,877 ha. (Scale Up 2012). Based on an interview with Head Office of PFMA III Pekanbaru, Riau Province Forest Area covering \pm 5,406,992 ha (SK. 903/MENLHK/SETJEN/PLA.2/12/ 2016) and more than $39.5 \%( \pm 2,134,000$ hectares $)$ have occurred the tenurial conflicts.

Forests area are controlled by corporations, leaving little area for the villagers

Community The State forest area in Riau Province Based o $n \quad D$ e c r e e M o E F $\quad \mathrm{N} \mathrm{u} \mathrm{m} \mathrm{b} \mathrm{e} \mathrm{r}$ SK.903/MENLHK/SETJEN/PLA.2/12/2016 on December 7,2016 , is $\pm 5,406,992$ ha (Table 1). Based on Riau Forest Environmental and Forest Service Statistics (2014), the usage of the state forest area of Riau Province which has been covered by permit of forestry corporation covering \pm 2,394,027.97 ha (Table 2).

In 2013, 4,226 ha of village forest work area was established in Segamai and Serapung, and it was the first and only work area for village forests in Riau Province. Compared with the forest domination by corporations in Riau Province, the determination of the village forest working area is only $0.17 \%$, an amount that very small compared to the domination of the forest by the forestry company (Figure 2)

The program of social forestry initiated by the state is supposed to restore the forest village community masters in order to regain access to the forest. However, the effort of village people to get $0.92 \%$ in Kampar Peninsula through social forestry program needs a series of strategies through a long struggle, and the communities were also faced with competition for remaining forest land vis a vis with the biggest forestry company within the ecosystem restoration schemes. The two biggest pulp producers, Asian Pulp \& Paper (APP) and Asia Pacific Resources International Holdings Limited (APRIL), got hold of large concession

Table 1 The forest area in Provinsi Riau

\begin{tabular}{lr}
\hline \multicolumn{1}{c}{ Type } & Area (ha) \\
\hline Conservation forest & 630,753 \\
a $\quad$ Nature reserve area & 286,516 \\
b $\quad$ Nature conservation area & 45 \\
c $\quad$ Nature preserve & 21,293 \\
d $\quad$ Wildlife reserve & 239,959 \\
e $\quad$ National parks & 81,967 \\
f Nature park & 973 \\
Protected forest & 233,910 \\
Limited production forest & $1,017,318$ \\
Production forest & $2,339,578$ \\
Production forest that can be converted & $1,185,433$ \\
\hline
\end{tabular}


Table 2 The usage of the State Forest Area in Riau Province

\begin{tabular}{lcr}
\hline \multicolumn{1}{c}{ Forestry Corporation Permit } & Unit Management & Area (ha) \\
\hline Natural Forest Corporation & 4 & 229,128 \\
Forest Plant Corporation & 58 & $1,660,293$ \\
Ecosystem Restoration Corporation & 4 & 116,977 \\
Non-Timber Product Corporation & 1 & 19,900 \\
Lending Use of Forest Area & 82 & 367,729 \\
Village Forest & 2 & 4,226 \\
- PelalawanDistrict & 2 & 2,270 \\
a Segamai Village Forest & 1 & 1,956 \\
b Serapung Village Forest & 1 & 0 \\
- KepulauanMerantiDistrict & 0 & 0 \\
- BengkalisDistrict & 0 & 0 \\
- Indragiri Hulu District & 0 & 0 \\
- Indragiri HilirDistrict & 0 & 0 \\
- Kampar District & 0 & 0 \\
- Rokan Hilir District & 0 & 0 \\
- Rokan Hulu District & 0 & 0 \\
- Kuantan Singingi District & 0 & 0 \\
- Dumai City & 0 & 0 \\
- Pekanbaru City & 0 & \\
\hline
\end{tabular}

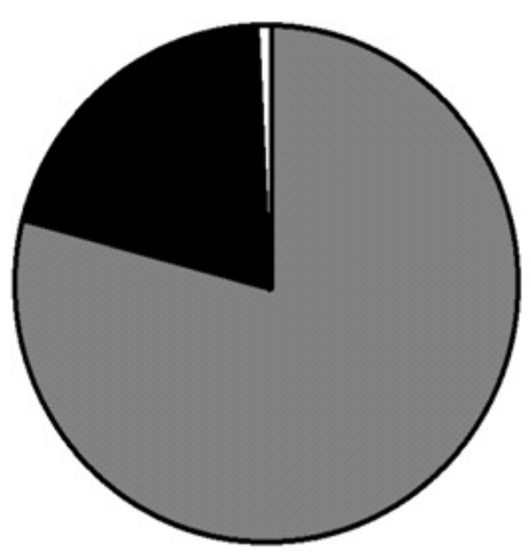

Figure 2 The domination of the forest permit by the Forestry Company. Industrial tree plantation $(\square)$, restoration ecosystem $(\square)$, village forest Segamai and Serapung ( $\square$.

areas for industrial tree plantations (Overbeek et al. 2012).

APRIL Group established the Restoration Ecosystem Riau (RER) permit granted by the Indonesian state in November 2012. RER is a multi-part project to restore and conserve an area of ecologically important peat forest in Indonesia's Sumatera Island. The project consists of 130,000 ha on the Kampar Peninsula and another 20,000 ha on the nearby Padang Island. Ecosystem restoration permits was granted in production forest areas have taken most of the reserve area for social forestry covering 12,360 ha $(\mathrm{MoF}$ Number SK 3803/Menhut-VI/BRPUK/2012 on June 29, 2012). This land acquisition has caused the Teluk Meranti and Pulau Muda Village has lost their village forest. The phenomenon of expansion of large-scale "green/ conservation business" such as ecosystem restoration is one of the motives of the land grabbing mechanisms of people around the forests as land acquisition process (Zoomers 2010; Wofford et al. 2013; Locher 2015).

The counter-hegemony and the social movement of the forest village community Community??? The Gramscian hegemony counter concept works analyze dominant or hegemonic dominant social and cultural forces and then move on to gather strength or counter-hegemony, an effort of resistance to reduce or eliminate and even fight for a new hegemony. Through counter-hegemony can be seen how a person or a group moves to form and fight for a separate hegemony as a resistance to an absolute domination. For Gramsci, intellectuals have a crucial role in creating a hegemonic political. Organic intellectuals of a particular class, which can help to develop a class identity. They are the ones who can develop a class strategy and advance the concept and make the whole community united as a subordinate or counter-hegemonic social force called movement (Cox 1992; Hunt 1990; Lukes 2005; Sugiono 2006; Patria \& Arief 2009).

The condition of forest villagers in Riau as an illustration of the condition of the beleaguered village community by the biggest forestry company. This forestry company controls much of the land that more than about 2 million ha of forests 
in Riau Province of Sumatera (Overbeek et al. 2012). Villagers living on the edge of the forest are facing the impacts of the forest industry. The condition of limitations the villagers as if deliberately created to dampen all the resistance of people who are aware of their rights to the forest. The NGOs take an intensive approach to the village community to advocate and raise consciousness about the position of communities entitled to legal governance within the forest areas.

In 2010, NGOs along with village communities on the Kampar Peninsula had initiated proposals for village forest licenses to MoEF. This proposal has become an attempt to counter-territorially state the political forest that has been created by the state and has given forest control to forestry companies. At that stage, NGOs were organic intellectuals. As an organic intellectual, they must start from revealing the reality of the life of the community, and actively participate in the life of the community, by trying to instill the new consciousness that reveals the depravity of the old system (Hunt 1990; Sugiono 2006).

Uncovering the strategy against the hegemony At least two main discourses that encourage the movement of NGOs in Sumatera are which are the deforestation and forest degradation and the injustice of access to the land of the village community. On the other hand, the uncertainty of the tenure law causes the vulnerable citizens' community to be criminalized, threaten the safety and living space of people in Sumatera in general and in Riau Province in particular. According to an opinion from Moeslim, Coordinator of Jikalahari Riau:

"from the 1.2 million ha reserves of forest areas, as in the indicative guidance for 2012 forest area utilization, only 12 thousand ha are allocated specifically for the people's forest. Then, although there are 86 thousand ha of community forest plantation program (HTR) reserves, it is not purely the property of the people because the permit of the peoples' plantation forest is generally just a ruse for the fulfillment of paper industry raw materials, meaning for the giant industrial and corporate interests in Riau"

Moreover, another explanation from the Director of Yasayan Mitra Insani (YMI) Zainuri Hasyim, in an interview at his office:

"That the starting point for the movement of NGOs in Riau originated from two public issues namely the first environmental degradation in the form of deforestation and degradation existing in the forest, and the second the injustice of access to the community for the management of forest areas that have been practiced... If you look at the data there are only a few percents for the community, even at that initial stage, we consider the percentage of the community is not considered ... So far, people are given hope by the company with the pattern of social forestry imposed into the form of village community forest Plantation Program which is managed by the company maintains a plant life space in the industrial tree plantation concession with a partnership pattern as social forestry and corporate social responsibility. The model of forestry is considered a form of cooperation that is very detrimental to the village community."

The discourse is a consciousness that encourages NGOs to assist to strengthen people's understanding of their rights to forest areas. Zainuri Hasyim added more explanation:

"This effort gives a lesson that it is possible for people's access to production forests for village community and space is contested with many parties... but done elegantly (not with money and follow the rule), a utopia to gain governance space for people in the depletion of forest land and the enormous voracious corporate nature of forest land the enormous voracious corporate nature offorest land".

The forceful effort to reach a village forest as a counterhegemony According to Zaynuri Hasyim basically, the existence of this village forest does not provide a solution to the demands on the fulfillment of village community rights in full and intact forest management. There have been longstanding efforts to revise Law Number 41 of 1999 on Forestry which is considered to be a major obstacle to the existence of village community rights over forests. The insistence on the realization of indigenous forests, which many consider is the right to restore the rights of the village community in an essential, does not end up in a binding and operational legal basis. Through the Village CommunityCentered Monitoring Program between 2007 and 2012, YMI Riau conducted advocacy to villagers in the Kampar Peninsula area, in Teluk Binjai Village, Teluk Meranti Village, Pulau Muda Village, Segamai Village, and Serapung Village at District of Pelalawan. The Donor support becomes the strength of YMI to raise consciousness and empowerment of forest villagers and the project goal is that the climate mitigation efforts in Indonesia respect the rights of indigenous peoples and local communities, and build from village community-based forest management systems to develop effective ways of reducing GHG emissions from deforestation and land use change, while at the same time improving rural village community livelihoods. Donor list of YMI is from The Samdhana Institute - An Asian Center for Social and Environmental Renewal, The Asian Foundation (TAF), Ford Foundation, Siemens Food Foundation (Finland), IUCN NL (the Dutch national committee of the International Union for Conservation of Nature, and CLUA (Climate Land UseAlliance).

The facts of villagers and their relation to the forest Villagers in the Kampar peninsula has utilized forests as a source of economic income. They were collected timber and other forest products in the open access area of forest, and there were strongly believed that would not destroy the forests. They have viewed the industrial tree plantations were destroying the forest and had made the canals transformed the peatland become a dry area and increase the risk of fire. Since the issuance of Presidential Instruction Number 4 in 2005 concerning Eradication of Illegal Logging and its Distribution in All Regions of the Republic of Indonesia, Villagers have stopped their activity and gradually stopped village community economic activities because what they 
did an illegal activity.

The organic intellectuals has build community consciousness The village community institutions must be prepared and strengthened by NGO to be compatible with regulation in MoEF Decree number P.49/Menhut-II/2008. The village community must become conscious of their right to obtain the village forests permit. It is called a Social Preparation that was meant for the village community to understand how to manage the forest well. Social preparation is vital to strengthen village community institutions for the implementation of a program, especially for beneficiaries. The success of a program is determined by how much the outside parties build village community institutions by doing social preparation (Hasan \& Syufri 2013).

Social movement in building the village community's economy According to Laclau and Mouffe's theory, peoples' view of the world is a product of discourses. This theory does not negate the presence of a fact, but it believes that objects and phenomena can be meaningful just through the valve of hegemonic discourse on the community and see social movements in the context of antagonistic relationships in the community. That the most critical point of analysis of ideological conceptions operated in Gramscian hegemony is to study concerning how to describe the new hegemonic formations. The hegemonic formation is the materialization of a social articulation, in which social relations mutually provide mutual conditions of existence, a hegemonic formation is always centered on certain social relationships which guarantee the centrality of the struggle. A hegemonic (discursive) formation presupposes a unifying principle that establishes an equivalence among the differential positions of the ensemble in opposition to a common enemy (Hutagalung 2008; Dabirimehr \& Fatmi 2014; Deseriis 2017).

To increase the village community's trust to NGOs, efforts were made to embrace and build village community institutions by living and mingling with the village community. NGOs brought economic programs to provide alternative livelihoods for rural communities because they had lost economic resources from the forest. NGOs created a social movement that invited people back to farming under the name of the Social Movement Returning to farm fields. The Pelalawan District states that Segamai Village, Teluk Meranti Sub-District and Serapung Village, Kuala Kampar Sub-District are the largest corn producers in the district (CSAoP 2015). This agricultural activity has long been abandoned when forest timber became the primary source of income for rural communities. The movement to return to agricultural land has become a movement to restore people's confidence to get out of economic difficulties. The social movement back to the farm fields was able to attract villagers to re-plant rice and corn in the farm fields because there was an easy return on capital provided by only planting forest trees and ensuring that the trees can grow (bio-rights approach). NGOs had provided a consciousness to the village communities that they have an access right to the forest. This a consciousness had become a hegemonic discourse at the village community level to develop strategies to capture the remaining forests in their villagers.
Recognizing to the security threats of villagers The activities of collecting village potentials and recognizing the security threats of village communities have opened up the villagers' consciousness that every change in forest functional would become threatened them so that a discourse that they must take the remaining forest becoming a hegemonic discourse. As Polanyi (2001) argues, countermovements are formed because people recognize the risk of destruction and develop protective measures to rebuild their lives. The result of the participative mapping who supported by NGO is known to the existence of forest area of 26,000 ha also located in the administrative area of Teluk Meranti Village, Pulau Muda Village, Segamai Village, and Serapung Village. So far, the forest land has been controlled by the forestry company. The community antagonists are awakened in identifying common enemies in companies that control their land in the village as a threat to community. The existence of these companies does not necessarily reduce the area of village administration. The above conditions, coupled with the apparent reality of the minimal contribution of forestry companies to improving the welfare of the village community, as well as the escalation of conflicts that often and continues to be the motivation of community to change the current condition (status quo) by changing the condition. The community must regain the remaining forest that could be managed by villagers. The opportunity to get access to remain forest, just only through a social forestry scheme. The understanding that YMI has built and nurtured the community as a social preparation for the societies capable and ready to carry out social movements seizes the remaining forests in their villages through the permit of village forest schemes. Investment from Industrial Tree Plantations has changed the forest cover and has resulted in the loss of village community access to the forest. The community has also been confronted with the fact that the state also issued permits for ecosystem restoration on 150,000 hectares of forest land. The management of the forest land is also not given to the village community. Non-governmental organizations have given the consciousness of the village community to make a real movement to capture the remaining forests, in the end, the discourse has become a hegemonic discourse that can unite the various interests of the village community in the forest. Regarding this matter the Village Head of Serapung said:

"This village forest will restore our Marwah (dignity) as a community whose life cannot be separated from the forest but do not currently have forest."

Hegemonic discourse in the villages of Segamai and Serapung has been formed. This discourse has formed the same logic (equality of struggle) in facing the challenges that will be fought for. The hegemonic center is needed to develop counter-hegemonic strategies. Youth leaders and village heads have played the hegemonic center (the master signifier) in the context of the struggle of the Segamai and Serapung communities. The hegemonic center in Segamai Village has been played by the village secretary who is a youth figure, while the Segamai Village head has played the hegemonic center in Serapung Village. Through the master signifier, the villagers have started a hegemony formation to fight for the village forest management rights in their village. 
The regional state does not support social forestry The Governor of Riau was paid little attention to the social forestry program because after 2 years had passed, he still did not permit Rights of Village Forest Management (RVFM) or Hak Pengelolaan Hutan Desa (HPHD) to the people of Segamai Village and the Serapung Village. Even though the determination of the village forest work area by the forestry ministry through the Minister of Forestry's letter Number 154 and 155/Menhut-II/2013 will be expired. The villagers of Segamai and Serapung hope that the Governor of Riau will soon sign the RVFM so that every activity organized by the Village forest management agency (VFMA) in their village forest area will become clear. However, over time RVFM was not published by the Riau Province Government. Serapung and Segamai Village Community in Pelalawan District filed a protest to the Governor of Riau Province because of not issued the RVFM yet. Until the end of the expiry of the Decree on the Working Area of Decree of the Minister of Forestry No 154 and 155/Menhut-II/2013 on March 8, 2015, RVFM has not been signed by the Governor of Riau. Finally, on August 24, 2015, Minister of Forestry and Environment, issued Decree Number. SK.342/Menlhk-Setjen/2015 on Stipulation of Segmented Forest Working Areas of Segamai and Decree Number SK. 343/Menlhk-Setjen/2015 on Determination of Segmented Forest Working Areas of Serapung, based on Ministerial Regulation P.89/MenhutII/2014 on Village Forest. The authority in this regulation for the issuance of RVFM is still in the hands of the Governor. Now, Under Regulation of the Minister of Forestry and Environment Number 80 P.83/MENLHK/ SETJEN/KUM.1/10/2016 on Social Forestry, the authority of granting RVFM is now taken over by the Minister. Finally, In March 2017, the MoEF issued RVFM to the people of Segamai and Serapung villages to provide legal certainty for the village forest area in Segamai and Serapung.

Submission of village forests and evidence of governmental abandonment against the community To obtain the Establishment of the Village Forest Working Area (VFWA) even takes more than two years (May 2010 to March 2013) without ensuring results for each stage of the submission procedure. Since the establishment of the Village Forest Working Area until its expiry date ends in March 2015, the Governor refuses to issue RVFM permits and leaves the public in the status quo until VFWA expires. To maintain territoriality, the villagers urge the Minister of Environment and Forestry to re-establish the VFWA Decree. Finally, Minister of Environment and Forestry issued a decree on the extension of VFWA. After all this time the Governor of Riau refused to grant RVFM, finally, the authority to issue RVFM was taken over by Minister of Environment and Forestry based on the new Social Forestry Regulation Number P.83/MENLHK/SETJEN/KUM.1/10/2016 dated October 25, 2016, Right of Village Forest Management issued by the Ministry of MoEF in March 2017. The village forest as a counter territorialization by village communities in Kampar Peninsula Riau finally gained legitimacy by the state.

It took seven years (May 2010 to March 2017) for Segamai and Serapung villages to got their territory in a production forest area. This village forest permit became the first in Riau Province and to get it was not an easy job but requires a series of political work. The remaining forest space becomes the arena of competition by various actors and interests in the forest. The social forestry program presented is still complicated to access by the village community, this is due to the government's discourse that sees rural communities as unable to carry out forest management. Granting access to forests is still considered high risk of forest land conversion and increase the risk of environmental degradation in the form of illegal logging, conversion of forest land into gardens, expansion of settlements, and will increase the potential for forest fires, as well as other negative risks caused by the community. The discourse about the community is so healthy that the community is considered as a disturbing actor in scientific forest management.

According to Fortman (1989) in Thompson (1999), the Indonesian foresters' (who worked in the forestry company or as the regulator in government) seen the local people are incompetent to forest management. As professionals, a forester does not like to be directed by local people that do not know much about silviculture. Through consulting with villagers and local tribes is contrary to what they have learned about forestry. The promotion of foresters working in the field remains centered on whether they had succeeded in planting trees, increasing productivity or saving money, and does not on whether the community succeeds in managing their groups and improving their welfare.

\section{Conclusions}

This study has shown that people want an equal position as a subject, who also gets a part of the forest area managers. Un-Humanist forest management which only pursues economic growth and does not take sides with the community will present a repressive state. When the boundaries of community subsistence were violated there will be resistance and opposition. Some resistances disguised or open to voice the injustice to the company, state or bureaucratic elites. The villagers' resistance has diverse backgrounds of motives. Marwah or local people's dignity for forest and forest management in their villages creates a discourse to seize the remaining forest. The discourse continues to be produced reproduced to grow antagonistic boundaries between communities and land and forest authorities. The discourse sizes the remaining forest by the company into a hegemonic discourse, to unite the community in gaining the right to manage the forest area.

According to Gramsci theory, NGOs are organic intellectuals that play an essential role in the capacity building of communities. NGO has created consciousness for the public to counter-hegemony. When dominant groups lose legitimacy, NGOs will carry out counter-hegemony movements. The consciousness raised is that the village community must get the space to manage and access to the forest because the state's hegemony over forests has been unfair. To be able to carry out the struggle for the remaining forests is to increase the capacity of the community through social preparation with the creation of food security and improvement of the local economy. NGOs can increase public consciousness to seize the remaining forest in their village. State hegemony over forests has been built and 
maintained since the colonial era and has eliminated community access to forests. Indeed the states' intrinsic interests in forests are not merely to maintain forest cover, but rather to maintain the status of forest areas as state property. Village forest as a model of social forestry is politically a form of the territorial counter for other parties who will access their forests. However, theoretically, it is a form of submission of the village community to the hegemony of the state, because the primary condition of the village community can get village forest is the recognition of the existence of forest area as state property, and must obey the rules that apply in the state forest. At this point, the Social Forestry Program is not a form of counter-hegemony (victory) of the people overstate hegemony in forest areas that have been going on since the colonial era, but instead strengthens the state's hegemony over forests (reinforcing hegemony). Social forestry becomes a way to find the best slice between the states' interests in the forest area and the community's need for forest areas. The social forestry program is in the process of obtaining an intrinsic interest from the community that requires arable land and a country that wants to strengthen the recognition (legitimacy) of the community over the status of forest areas controlled by the state. The strategy that has been used in the case of the struggle for remaining forest land by NGOs and village communities in the Pelalawan District can be used as an opportunity to be used by local communities elsewhere.

Overall this study has shown that there is an improvement in more equitable forest management in Indonesia. The forest management rights in villages will give the community confidence in the subject of forest development. There are not enough alignments in which create a concrete base for forest management, however, with enough action from the state, this has different outcomes. Eventually, once the community became the subject of the first forestry development that manages communal village forests in Riau Province and stands parallel to the forestry companies in the village.

\section{Acknowledgment}

The authors would like to express sincere gratitude to Indonesia's Ministry of Environment and Forestry for providing funding for the study under "scholarship school program."

\section{References}

Bromley S. 1991. American Hegemony On World Oil: The Industry, World System, and Economy. Great Britain: The Pennsylvania University Press.

Arsyad Benjamin S. 2011: The Power in Carbon. A NeoGramscian explanation for the EU's Adoption of Emissions Trading in Engels. Anita, editor. Global Transformations Towards a Low Carbon Society 4 (Working Paper Series). Hamburg: University of Hamburg/KlimaCampus

Bloomfield MJ. 2012. Is forest certification a hegemonic force? The FSC and its challengers. Journal of Environment \& Development 21(4):391-413. https://doi.org/10.1177/1070496512449822
Bocock R. 1986. Hegemony. London: Tavistock Publication

Buchy M. 2000. Forestry Department, Forestry: from a Colonial Discipline to a Modern Vision. Keynote Paper. Workshop on Changing Learning and Education in Forestry, SaPa, Vietnam. 1619 April 2000. Social Forestry Support Programme, Vietnam. $18 \mathrm{p}$. http://www.socialforestry.org.vn. [3 November 2016].

Budiono R. 2017. Analisis hubungan negara dan masyarakat dalam pengelolaan sumber daya hutan (studi kasus Kabupaten Pelalawan Provinsi Riau). [dissertation]. Bogor: Bogor Agricultural University.

Bungin HMB. 2007. Penelitian Kualitatif Komunikasi, Ekonomi, Kebijakan Publik dan Ilmu Sosial. Jakarta: Lanilla Kencana Prenada Media Group.

Cascão A. 2008. Ethiopia-challenges to Egyptian hegemony in the Nile Basin. Water Policy 10(2):13-28.

Central Statistics Agency of Pelalawan Regency (CSAoP). 2015. Kecataman Teluk Meranti \& Kuala Kampar dalam Angka. Katalog BPS nomor 1102001.1404042 \& 1102001.1404040, ISBN 9794846112 \& 979484609 0. www. pelalawankab.bps.go.id. [13 oktober 2017].

Cox RW. 1992. Towards a post-hegemonic conceptualization of world order: Reflections on the relevancy of Ibn Khaldun. In Rosenauand JN, Czempiel EQ, editors. Governance without Government Order and Change in World Politics. Cambridge: Cambridge University Press pp. 132-159. https://doi.org/10.1017/ CBO9780511521775.007

Cox RW. 1983. Gramsci, hegemony, and international relations: An essay in method. Millennium: Journal of International Studies 12(2):162-175 https://doi.org/ $10.1177 / 03058298830120020701$

Coughlan D, Miller MB. 2014. The Sage Encyclopedia of Action Research. London: SAGE Publication Ltd. https://doi.org/10.4135/9781446294406.

Dabirimehr A, Fatmi MT. 2014. LACLAU and Mouffe's theory of discourse. Journal of Novel Applied Sciences 3(11):1283-1287.

Deseriis M. 2017. Technopopulism: The emergence of a discursive formation. tripleC: Communication, Capitalism \& Critique 15(2):441-458 https://doi.org/ 10.31269/triplec.v15i2.770

Effendy T. 2008. Bujang Tan Domang, Sastra Lisan Orang Petalangan. Jakarta: Yayasan Obor Indonesia.

Forest Environmental and Forest Service Statistics. 2014. Statistik Dinas Kehutanan Provinsi Riau. Bidang Planologi Kehutanan. Pekanbaru: Dinas Kehutanan Propinsi Riau.

Fay C, Michon G. 2005. Redressing forestry hegemony 
when a forestry regulatory framework is best replaced by an agrarian one, forests, trees and livelihoods. Forests, Trees and Livelihoods 15(2):193-209. https://doi.org/10.1080/14728028.2005.9752520

Geary K. 2012. 'Our Land, Our Lives': Timeout on the global land rush OXFAM BRIEFING NOTE, Oxfam GB for Oxfam International. ht t p:// policypractice.oxfam.org.uk/publications/our-land-our-livestime-out-on-the-global-land-rush-246731. [4 Juni 2016].

Gerber JF. 2011. Conflicts over industrial tree plantations in the south: Who, how and why? Global Environmental Change 21(1):165-76. https://doi.org/10.1016/ j.gloenvcha.2010.09.005

Hardjanto. 2003. Keragaan dan pengembangan usaha kayu rakyat di Pulau Jawa [disertasi]. Bogor: Bogor Agricultural University.

Hardojo AP. 2008. Mendahulukan si Miskin. Buku Sumber Bagi Anggaran Pro Rakyat. Yogyakarta: LKIS.

Hasan M, Syufri. 2013. Persiapan sosial dan penguatan kelembagaan bagi penerima manfaat dalam menunjang Program REDD "Reduction Emission from Deforestation and Degradation". Jurnal Academica Fisip Untad 5(2):1079-1084.

Hendarto. 1993. Mengenal Konsep Hegemoni Gramsci dalam Diskursus Kemasyarakatan dan Kemanusiaan. Jakarta: Gramedia Pustaka Utama.

Hunt A. 1990. Rights and social movements: Counterhegemonic strategies. Journal of Law and Community 17(3): 309-328. https://doi.org/10.2307/1410156.

Hutagalung D. 2008. Hegemoni dan Demokrasi RadikalPlural: Membaca Laclau dan Mouffe. In: Laclau E, Mouffe C. Translated from: Hegemoni dan Strategi Sosialis. Yogyakarta: Resist Book.

Iskandar. 2015. Hukum Kehutanan, Prinsip Hukum Pelestarian Lingkungan Hidup dalam Kebijakan Pengelolaan Kawasan Hutan Berkelanjutan. Bandung: Mandar Maju.

Laclau E, Mouffe C. 2008. Hegemoni dan Strategi Sosialis: Post Marxisme dan Gerakan Sosial Baru. Yogyakarta: Resist Book.

Lansing D. 2014. Discourse and the production of territorial hegemony: Indigenous peoples, the United Fruit Company and the capitalist state in Costa Rica, 18721916. Journal of Historical Geography 45:38-49. https://doi.org/10.1016/j.jhg.2014.04.001

Lee JWY, Tang WS. 2016. The hegemony of the real estate industry: Redevelopment of 'Government/Institution or Community' (G/IC) land in Hong Kong. Urban Studies 54(15):3403-3422. https://doi.org/10.1177/004209801 6679607
Leirissa RZ. 1999. VOC sebagai sejarah sosial. Wacana 1(1):

Locher M. 2015. The global land rush local land rights and power relations: European forestry investments in Tanzania. [dissertation]. Gottingen: the University of Zurich.http://doi.org/10.5167/uzh-117347

Lukes S. 2005. Power, Second Edition: A Radical View. Second Edition. Hampshire: Palgrave MacMillan.

Machmur AS, Sutoyo W. 1999. Dinamika Proses Lahirnya Undang-Undang Republik Indonesia No 41 Tahun 1999 Tentang Kehutanan. Jakarta: Departemen Kehutanan dan Perkebunan.

McCarthy JF, Jacqueline AC, Afiff S. 2012. Trajectories of land acquisition and enclosure: development schemes, virtual land grabs, and green acquisitions in Indonesia's Outer Islands. The Journal of Peasant Studies 39(2):521-549.

Nugroho B. 2013. Reformasi institusi dan tata kepemerintahan: Faktor pemungkin menuju tata kelola kehutanan yang baik. Kembali ke jalan lurus: Kritik penggunaan ilmu dan praktek kehutanan Indonesia. Yogyakarta: Nailil Printika.

Nugroho B. 2011. Land rights of community forest plantation policy: Analysis from an institutional perspective. Jurnal Manajemen Hutan Tropika 17(3):111-118.

Nurrochmat DR, Hasan MF, Suharjito D, Hadianto A, Ekayani M, Sudarmalik, Purwawangsa H, Mustaghfirin, Ryandi ED. 2012. In: Nurrochmat M, Hasan M, editors. Ekonomi Politik Kehutanan. Mengurai Mitos dan Fakta Pengelolaan Hutan, Second edition INDEF, Jakarta (revised version (in Indonesian)).

Nurrochmat DR, Iin S, Ekayani M, Hadianto A. 2010. Neraca Pembangunan Hijau, Konsep \& Implikasi Bisnis Karbon Tata Air di Sektor Kehutanan. Bogor: IPB Press.

Nurrochmat DR. 2005. The Impacts of Regional Autonomy on Political Dynamics, Socio-Economic and Forest Degradation. Case of Jambi-Indonesia. Goettingen: Cuvillier Verlag.

Nurrochrnat DR, Darusman D, Ruchjadi D. 2014. Rekonstruksi sistem tenurial kehutanan. Risalah Kebijakan Pertanian dan Lingkungan 1(1):24-29.

Menga F. 2016. Reconceptualizing hegemony: the circle of hydro-hegemony. Water Policy 18(2):401-418.

Onghokham. 2014. Runtuhnya Hindia Belanda. Jakarta: Gramedia Pustaka Utama.

Overbeek W, Kröger M, Gerber JF 2012. An Overview of Industrial Tree Plantations in the Global South: Conflicts, Trends, Resistance Struggles. Ejolt Report No 3. Helsinki: WRM-University of Helsinki.

Patria N, Arief A. 2009. Antonio Gramsci: Negara dan 


\section{Hegemoni. Yogyakarta: Pustaka Pelajar}

Peluso NL. 2006. Hutan Kaya, Rakyat Melarat: Penguasaan Sumber Daya dan Perlawanan di Jawa. Yogyakarta: Khopalindo.

Perkins HA. 2011. Geoforum Gramsci in green: Neoliberal hegemony through urban forestry and the potential for a political ecology of pratice. Geoforum 42:558-566. https://doi.org/10.1016/j.geoforum.2011.05.001.

Prabowo SA, Basuni S, Suharjito D. 2010. Konflik tanpa henti: Permukiman dalam kawasan Taman Nasional Halimun. Jurnal Manajemen Hutan Tropika 16(3):137-142.

Perkins HA. 2011. Gramsci in green: Neoliberal hegemony through urban forestry and the potential for a political ecology of praxis. Geoforum 42:558-566. https://doi.org/10.1016/j.geoforum.2011.05.001

Pranoto SW. 2010. Jawa (Bandit-Bandit Pedesaan) Studi Historis 18501942. Yogyakarta: Graha Ilmu.

Polanyi K. 2001. The Great Transformation: The Political and Economic Origins of Our Time, 2nd ed.

Rahman NF. 2017. Petani \& Penguasa: Dinamika Perjalanan Politik Agraria Indonesia. Yogyakarta: Insist Press.

Rajagukguk E. 1995. Hukum Agraria, Pola Penguasaan Tanah dan Kebutuhan Hidup. Cetakan I. Jakarta: Chandra Pratama.

Samad RS. 2010. Negara dan Masyarakat Studi Penetrasi Negara di Riau Kepulauan Masa Orde Baru. Yogyakarta: Pustaka Pelajar.

Servillo L. 2010. Territorial cohesion discourses: Hegemonic strategic concepts in European spatial planning. Planning Theory \& Practice Journal 11(3):397-416. https://doi.org/10.1080/14649357.2010.500135.

Scale Up. 2012. Laporan Tahunan (ringkas) Konflik Sumber Daya Alam di Riau Tahun 2008, 2009, 2010, 2011. Pekanbaru: Scale Up dan IMN.

Sitorus MTF. 1998. Penelitian Kualitatif: Suatu Perkenalan. Bogor: Kelompok Dokumentasi Ilmu-limu Sosial untuk Laboratorium Sosiologi, Antroplogi, dan Kependudukan. Bogor: Institut Pertanian Bogor.

Soekiman D. 2011. Kebudayaan Indis: Dari Zaman Kompeni Sampai Revolusi. Jakarta: Komunitas Bambu.

Strauss A, Corbin J. 1990. Basics of qualitative research:
Grounded Theory Procedures and Techniques. Newbury Park, CA: Sage Publications.

Sugiono M. 2006. Kritik Antonio Gramsci Terhadap Pembangunan Dunia Ketiga. Cetakan II. Yogyakarta: Pustaka Pelajar.

Suhendang E. 2013. Perkembangan Paradigma Kehutanan. Makalah disampaikan dalam Diskusi Pengelolaan Hutan Berbasis Ekosistem sebagai Pendekatan untuk Pengelolaan Hutan Indonesia dalam Paradigma Kehutanan Indonesia Baru. Diselenggarakan dalam rangka Ulang Tahun Emas Fakultas Kehutanan IPB (1963-2013). Bogor, Agustus 2013.

Sunyoto A. 2015. Kolonial Belanda dan Kekerasan Budaya Pasca 1926-1927. Downloaded from http://www.nu. or.id/post/read/64388/\%09kolonialisme- Belanda-dankekerasan-budaya-pasca-1926-1927. [3 Juni 2016].

Scattergood W. 2004. Dynamic Hegemony: Power, Cooptation, and Subversion in the Clash Between International Trade, Security, and Environmental Protection" Paper presented at the annual meeting of the International Studies Association, Le Centre Sheraton Hotel, Montreal, Quebec. Canada.

Tamagola T. 2006. Republik Kapling. Yogyakarta: Resist Book.

Thompson H. 1999. Social forestry: An analysis of Indonesian forestry policy department of economics, Murdoch University. Journal of Contemporary Asia 29(2):187-201 https://doi.org/10.1080/ 004723399800 00311

Zinzani A, Menga F. 2017. The circle of Hydro-hegemony between riparian states, development policies and borderlands: Evidence from the Talas Waterscape (Kyrgyzstan-Kazakhstan). Journal Geoforum 85:112-121. https://doi.org/10.1016/j.geoforum. 2017.07.019

Warne J. 2008. Contested Hydro-hegemony: Hydraulic control and security in Turkey. Journal Water Alternatives 1(2):271-288.

Wolford W, Borras Jr SM, Hall R, Scoones I, White B. 2013. Governing global land deals: The role of the state in the rush for land. Journal Development and Change 44(2):189210. https://doi.org/10.1111/dech.12017.

Wollenberg E, Belcher B, Sheil D, Dewi S, Moeliono M. 2004. Mengapa kawasan hutan penting bagi penanggulangan kemiskinan di Indonesia? Governance Brief 4(1). Forest and Governance Programme. Bogor: Center for International Forestry Research, CIFOR 